\title{
角形補強筋で拘束されたコンクリート柱の 軸方向応力度一歪度関係に関する研究 STRESS-STRAIN BEHAVIORS OF SQUARE CONFINED REINFORCED CONCRETE COLUMNS
}

\author{
加藤大介* \\ Daisuke KATO
}

\begin{abstract}
In order to evaluate ultimate strength and ductility of flexurally failing reinforced concrete members, the use of axial stress-strain relation models of concrete, which represent behaviors of concrete practically as far as in the range of descending part after maximum stress, will be necessary. In this study, two series of experiments were conducted in order to propose a more practical stress-strain relation model for square confined $\mathrm{R} / \mathrm{C}$ columns.

In series $A, 15$ square columns, each $150 \mathrm{~mm}$ square by $530 \mathrm{~mm}$ high, containing different arrangements of square steel hoops, were subjected to concentric axial force only. In series B, 26 square columns, each $150 \mathrm{~mm}$ square by $530 \mathrm{~mm}$ high, with different concrete strength $(400,600$, $\left.800 \mathrm{~kg} / \mathrm{cm}^{2}\right)$ and different reinforcement strength $\left(4000,8000,12000 \mathrm{~kg} / \mathrm{cm}^{2}\right)$, were subjected to concentric axial force only.

The stress - strain relation model was proposed based on the results of experiment series A and B. The increments of maximum stress and axial strain at maximum stress by hoop confinement were considered. The effects of square confinement were also considered in this model. Also, the negative stiffness of the descending part after maximum stress could be evaluated using confining stress by hoop reinforcement at the axial stress peak point. The ultimate axial stress could be evaluated using maximum confining stress by hoop reinforcement.
\end{abstract}

Keywords : reinforced concrete, stress-strain curve, square confined, high strength concrete, high strength reinforcement

鉄筋コンクリート，拘束効果，角形補強筋，高強度コンクリート，高強度補強筋

\section{1. 序}

本研究の目的は，角型補強筋により横拘束を受けるコ アコンクリート（横補強筋で囲まれた部分のコンクリー 卜を意味する) の平均的な軸応力度と軸歪度関係の評価 モデルを実験的に求めることである。

横方向に拘束を受けるコンクリートの挙動は拘束応力 により大きく変化することはよく知られており，この効 果を考慮したコンクリートモデルも多数提案されてい る。一方, 角形の横補強筋で拘束される鉄筋コンクリー 卜 (以下, RC) 造部材におけるコンクリートは, その 拘束圧は横補強筋折り曲げ部位置に集中的に作用するた め断面内および部材軸に沿って拘束圧が均一にはならな いことに着目して評価がなされており, 均等な側圧に置 換した研究 ${ }^{1)-31}$, 有効に拘束される体積が減少すること をモデル化した研究4) 6) , 角型補強筋の拘束機構に着目
した研究7)，さらに，横歪度の適合条件を考慮したも $の^{8), 91}$ ，等がある。

本研究では, 試験体の軸方向の最大応力度時には角型 補強筋の応力度は降伏応力度よりかなり低いレベルにあ り，そのために油圧による均等な拘束圧や円形補強筋に 比較してその拘束効果は低減すると考えた。すなわち, 角型補強筋の拘束機構に着目し, 軸歪度と横歪度の適合 条件を考慮して拘束応力度を実験的に評価し，この拘束 応力度を用いて角型補強筋により拘束されたコンクリー トのモデル化を行うことを武みた。一方，均等な横拘束 応力を受けるコンクリートの軸方向の最大応力度点は Richart らにより評価されているが101，本研究では角型 補強筋より生じるコアコンクリート内の平均拘束応力度 の軸方向応力度一歪度関係に及ぼす効果は均等圧のもの とほぼ等しいと考えた。また， $\mathrm{RC}$ 造部材が一般に角型 
の横補強筋に拘束された角型の断面を有することを考慮 して，その配筋法の詳細による影響を取り入れることに 重点を置いた。さらに，コンクリートおよび帯筋の材料 強度の組み合わせをパラメータにした実験も行い，適用 範囲の拡大を試みた。したがって，モデルは，横補強筋 比, 横補強筋間隔, 横補強筋径, 横補強筋強度, 横補強 筋形状 (スパイラル等), 横補強筋定着の詳細（フック,
溶接等), コンクリート強度, の効果を評価するものとし， 柱の断面形状, 繰返し載荷, 偏心加力等の影響は今後の 課題とする。

\section{2. 実験データ}

\section{1 実験概要}

本研究では大きく分けて A，Bの 2 シリーズの実験を

表一1（a ） シリーズAの試験体の諸元と実験結果

\begin{tabular}{|c|c|c|c|c|c|c|c|c|c|c|c|c|c|}
\hline \multicolumn{2}{|c|}{$\begin{array}{l}\text { 試験体 } \\
\text { 番号 }\end{array}$} & 試験体名 & $\begin{array}{l}\text { 带筋径 } \\
\text { と形状 }\end{array}$ & $\begin{array}{l}\text { ピッチ } \\
\text { S(m) }\end{array}$ & $\begin{array}{l}\text { コア内 } \\
\text { 帯筋比 } \\
\text { Pw }(\%)\end{array}$ & $\begin{array}{l}\text { コア最大 } \\
\text { 応力度 } \\
\sigma \mathrm{p} \\
\left(\mathrm{kg} / \mathrm{cm}^{2}\right)\end{array}$ & $\begin{array}{l}\text { コア最大 } \\
\text { 応力度時 } \\
\text { 軸歪 } \varepsilon p \\
\text { (micro) }\end{array}$ & $\begin{array}{l}\text { コア最大 } \\
\text { 応力度時 } \\
\text { 横歪 } \varepsilon \mathrm{t} \\
\text { (micro) }\end{array}$ & $\begin{array}{l}\text { コア終局 } \\
\text { 応力度 } \\
\sigma \text { up } \\
\left(\mathrm{kg} / \mathrm{cm}^{2}\right)\end{array}$ & $\begin{array}{l}\text { 最大耐力以 } \\
\text { 後のコアの } \\
\text { 勾配 Eup } \\
\left(\mathrm{t} / \mathrm{cm}^{2}\right)\end{array}$ & $\begin{array}{l}\text { 带筋降伏 } \\
\text { 応力度 } \\
\sigma w y \\
\left(\mathrm{~kg} / \mathrm{cm}^{2}\right)\end{array}$ & $\begin{array}{l}\text { コンクリ } \\
\text { ート強度 } \\
\sigma_{\mathrm{B}} \\
\left(\mathrm{kg} / \mathrm{cm}^{2}\right)\end{array}$ & $\begin{array}{l}\text { 無拘束試 } \\
\text { 馱体最大 } \\
\text { 応力度 } \\
\left(\mathrm{kg} / \mathrm{cm}^{2}\right)\end{array}$ \\
\hline $\begin{array}{l}\dot{\Sigma} \\
y \\
1 \\
x\end{array}$ & $\begin{array}{l}1 \\
2 \\
3 \\
4 \\
5 \\
6 \\
7 \\
8\end{array}$ & $\begin{array}{l}\text { 2D10S140 } \\
2 D 10 S 93 \\
2 D 10 S 70 \\
2 D 6 S 93 \\
2 D 6 S 70 \\
\text { 2D6S47 } \\
\text { 2D6S35 } \\
\text { PC1 }\end{array}$ & $\begin{array}{l}2-D 10 \\
2-D 10 \\
2-D 10 \\
2-D 6 \\
2-D 6 \\
2-D 6 \\
2-D 6 \\
-\end{array}$ & $\begin{array}{r}140 \\
93 \\
70 \\
93 \\
70 \\
47 \\
35 \\
-\end{array}$ & $\begin{array}{l}0.72 \\
1.09 \\
1.45 \\
0.49 \\
0.65 \\
0.97 \\
1.31 \\
-\end{array}$ & $\begin{array}{l}212 \\
255 \\
261 \\
212 \\
244 \\
254 \\
272 \\
194\end{array}$ & $\begin{array}{l}4819 \\
5990 \\
6319 \\
6501 \\
5893 \\
5946 \\
9708 \\
1996\end{array}$ & $\begin{array}{r}814 \\
954 \\
1200 \\
1373 \\
1385 \\
1223 \\
1650 \\
-\end{array}$ & $\begin{array}{l}0 \\
0 \\
0 \\
0 \\
0 \\
0 \\
0 \\
0\end{array}$ & $\begin{array}{l}- \\
-3.9 \\
-3.9 \\
-4.3 \\
-4.3 \\
-2.7 \\
-1.5 \\
-\end{array}$ & $\begin{array}{l}3390 \\
3390 \\
3390 \\
3840 \\
3840 \\
3840 \\
3840\end{array}$ & $\begin{array}{l}271 \\
271 \\
271 \\
271 \\
271 \\
271 \\
+\quad 271 \\
271\end{array}$ & $\begin{array}{l}194 \\
194 \\
194 \\
194 \\
194 \\
194 \\
194 \\
194\end{array}$ \\
\hline $\begin{array}{l}\vdots \\
y \\
1 \\
x \\
2\end{array}$ & $\begin{array}{ll} & 9 \\
1 & 0 \\
1 & 1 \\
1 & 2 \\
1 & 3 \\
1 & 4 \\
1 & 5\end{array}$ & $\begin{array}{l}2 D 6 S 23 \\
3 D 6 S 70 \\
2 \phi 4 S 47 \\
2 \phi 4 S 35 \\
2 \phi 4 S 23 \\
3 \phi 4 S 70 \\
3 \phi 4 S 35\end{array}$ & $\begin{array}{l}2-D 6 \\
3-D 6 \\
2-\phi 4 \\
2-\phi 4 \\
2-\phi 4 \\
3-\phi 4 \\
3-\phi 4\end{array}$ & $\begin{array}{l}23 \\
70 \\
47 \\
35 \\
23 \\
70 \\
35\end{array}$ & $\begin{array}{l}1.99 \\
0.98 \\
0.38 \\
0.51 \\
0.78 \\
0.38 \\
0.77\end{array}$ & $\begin{array}{l}322 \\
263 \\
217 \\
242 \\
255 \\
244 \\
290\end{array}$ & $\begin{array}{r}11657 \\
5622 \\
5751 \\
5718 \\
5712 \\
5179 \\
8615\end{array}$ & $\begin{array}{r}2224 \\
1300 \\
837 \\
1470 \\
1477 \\
1960 \\
2857\end{array}$ & $\begin{array}{l}0 \\
0 \\
0 \\
0 \\
0 \\
0 \\
0\end{array}$ & $\begin{array}{l}-0.3 \\
-4.1 \\
-3.8 \\
-4.7 \\
-2.6 \\
-3.9 \\
-4.3\end{array}$ & $\begin{array}{l}3840 \\
3840 \\
4530 \\
4530 \\
4530 \\
4530 \\
4530\end{array}$ & $\begin{array}{l}250 \\
250 \\
250 \\
250 \\
250 \\
250 \\
250\end{array}$ & $\begin{array}{l}(179) \\
(179) \\
(179) \\
(179) \\
(179) \\
(179) \\
(179)\end{array}$ \\
\hline
\end{tabular}

(注 1) 主筋は全試駿体共通で $\phi 4\left(\sigma y=4290 \mathrm{~kg} / \mathrm{cm}^{2}\right)$ を4本使用。

（注2）無拘束試雅体最大志力度の（）つきは $\sigma 0=194 \cdot(250 / 271)$ て推定。

(b ) シリーズBの試験体の諸元と実験結果

\begin{tabular}{|c|c|c|c|c|c|c|c|c|c|c|c|c|c|}
\hline \multicolumn{2}{|c|}{$\begin{array}{l}\text { 試験体 } \\
\text { 番号 }\end{array}$} & 試酸体名 & 帶筋径 & $\begin{array}{l}匕^{\circ} ッ \\
S(\min )\end{array}$ & $\begin{array}{l}\text { コア内 } \\
\text { 带筋比 } \\
\operatorname{Pw}^{2}(\%)\end{array}$ & $\begin{array}{l}\text { コア最大 } \\
\text { 応力度 } \\
\sigma \mathrm{p} \\
\left(\mathrm{kg} / \mathrm{cm}^{2}\right)\end{array}$ & $\begin{array}{l}\text { コア最大 } \\
\text { 応力度時 } \\
\text { 軸歪 } \varepsilon p \\
\text { (micro) }\end{array}$ & $\begin{array}{c}\text { コア最大 } \\
\text { 応力度時 } \\
\text { 横歪 } \varepsilon \mathrm{t} \\
\text { (micro) }\end{array}$ & $\begin{array}{l}\text { コフ粼局 } \\
\text { 応力度 } \\
\text { oup } \\
\left(\mathrm{kg} / \mathrm{cm}^{2}\right)\end{array}$ & $\begin{array}{l}\text { 最大耐力以 } \\
\text { 後のコアの } \\
\text { 勾配 Eup } \\
\left(\mathrm{t} / \mathrm{cm}^{2}\right)\end{array}$ & $\begin{array}{l}\text { 帯筋降伏 } \\
\text { 応力度 } \\
\sigma w y \\
\left(\mathrm{~kg} / \mathrm{cm}^{2}\right)\end{array}$ & $\begin{array}{l}\text { コンクリ } \\
\text { ート強度 } \\
\sigma_{\mathrm{B}} \\
\left(\mathrm{kg} / \mathrm{cm}^{2}\right)\end{array}$ & $\begin{array}{l}\text { 無拘束試 } \\
\text { 驗体最大 } \\
\text { 岕力度 } \\
\left(\mathrm{kg} / \mathrm{cm}^{2}\right)\end{array}$ \\
\hline $\begin{array}{l}\vdots \\
y \\
1 \\
x\end{array}$ & $\begin{array}{l}1 \\
2 \\
3 \\
4 \\
5 \\
6 \\
7 \\
8\end{array}$ & $\begin{array}{l}\text { F4Y4S30 } \\
\text { F4Y4S60 } \\
\text { F4Y8S30 } \\
\text { F4Y8S60 } \\
\text { F4Y12S30 } \\
\text { F4Y12S60 } \\
\text { F4P-1 } \\
\text { F4P-2 }\end{array}$ & $\begin{array}{l}\phi 5.5 \\
\phi 5.5 \\
\phi 5.0 \\
\phi 5.0 \\
\phi 5.0 \\
\phi 5.0 \\
- \\
-\end{array}$ & $\begin{array}{l}30 \\
60 \\
30 \\
60 \\
30 \\
60 \\
- \\
-\end{array}$ & $\begin{array}{l}1.13 \\
0.57 \\
0.93 \\
0.47 \\
0.93 \\
0.47 \\
- \\
-\end{array}$ & $\begin{array}{l}491 \\
415 \\
503 \\
411 \\
478 \\
439 \\
442 \\
426\end{array}$ & $\begin{array}{l}5038 \\
3030 \\
4932 \\
3101 \\
5016 \\
4942 \\
2399 \\
2583\end{array}$ & $\begin{array}{r}1000 \\
836 \\
1374 \\
999 \\
970 \\
1537 \\
657 \\
487\end{array}$ & $\begin{array}{r}191 \\
84 \\
313 \\
137 \\
412 \\
164 \\
0 \\
0\end{array}$ & $\begin{array}{l}-12.9 \\
-13.0 \\
-\quad 6.5 \\
-12.9 \\
-\quad 5.0 \\
-19.4 \\
- \\
-\end{array}$ & $\begin{array}{c}3740 \\
3740 \\
8180 \\
8180 \\
10770 \\
10770 \\
- \\
-\end{array}$ & $\begin{array}{l}527 \\
503 \\
527 \\
503 \\
527 \\
503 \\
527 \\
503\end{array}$ & $\begin{array}{l}442 \\
426 \\
442 \\
426 \\
442 \\
426 \\
442 \\
426\end{array}$ \\
\hline $\begin{array}{l}\vdots \\
1 \\
1 \\
x\end{array}$ & $\begin{array}{ll} & 9 \\
1 & 0 \\
1 & 1 \\
1 & 2 \\
1 & 3 \\
1 & 4 \\
1 & 5 \\
1 & 6\end{array}$ & $\begin{array}{l}\text { F6Y4S30 } \\
\text { F6Y4S60 } \\
\text { F6Y8S30 } \\
\text { F6Y8S60 } \\
\text { F6Y12S30 } \\
\text { F6Y12S60 } \\
\text { F6P-1 } \\
\text { F6P-2 }\end{array}$ & $\begin{array}{l}\phi 5.5 \\
\phi 5.5 \\
\phi 5.0 \\
\phi 5.0 \\
\phi 5.0 \\
\phi 5.0 \\
- \\
-\end{array}$ & $\begin{array}{l}30 \\
60 \\
30 \\
60 \\
30 \\
60 \\
- \\
-\end{array}$ & $\begin{array}{l}1.13 \\
0.57 \\
0.93 \\
0.47 \\
0.93 \\
0.47 \\
- \\
-\end{array}$ & $\begin{array}{l}735 \\
705 \\
785 \\
753 \\
769 \\
737 \\
658 \\
662\end{array}$ & $\begin{array}{l}4880 \\
5290 \\
5448 \\
4948 \\
5135 \\
5135 \\
2814 \\
2726\end{array}$ & $\begin{array}{r}1586 \\
1230 \\
1378 \\
1386 \\
1338 \\
1511 \\
2117 \\
662\end{array}$ & $\begin{array}{r}191 \\
84 \\
313 \\
137 \\
412 \\
164 \\
0 \\
0\end{array}$ & $\begin{array}{l}-35.7 \\
-18.3 \\
-13.6 \\
-14.5 \\
-11.0 \\
-13.7 \\
- \\
-\end{array}$ & $\begin{array}{r}3740 \\
3740 \\
8180 \\
8180 \\
10770 \\
10770 \\
\hdashline\end{array}$ & $\begin{array}{l}761 \\
784 \\
761 \\
784 \\
761 \\
784 \\
761 \\
784\end{array}$ & $\begin{array}{l}658 \\
662 \\
658 \\
662 \\
658 \\
662 \\
658 \\
662\end{array}$ \\
\hline 部 & $\begin{array}{ll}1 & 7 \\
1 & 8 \\
1 & 9 \\
2 & 0 \\
2 & 1 \\
2 & 2 \\
2 & 3 \\
2 & 4 \\
2 & 5 \\
2 & 6\end{array}$ & $\begin{array}{l}\text { F8Y4S30 } \\
\text { F8Y4S60 } \\
\text { F8Y8S30 } \\
\text { F8Y8S60 } \\
\text { F8Y12S30 } \\
\text { F8Y12S60 } \\
\text { F8P-1 } \\
\text { F8P-2 } \\
\text { F8SP30 } \\
\text { F8SP60 }\end{array}$ & $\begin{array}{c}\phi 5.5 \\
\phi 5.5 \\
\phi 5.0 \\
\phi 5.0 \\
\phi 5.0 \\
\phi 5.0 \\
- \\
- \\
\phi 5.0 \\
\phi 5.0\end{array}$ & $\begin{array}{l}30 \\
60 \\
30 \\
60 \\
30 \\
60 \\
- \\
- \\
30 \\
60\end{array}$ & $\begin{array}{c}1.13 \\
0.57 \\
0.93 \\
0.47 \\
0.93 \\
0.47 \\
- \\
- \\
0.93 \\
0.47\end{array}$ & $\begin{array}{l}811 \\
736 \\
878 \\
815 \\
889 \\
827 \\
- \\
773 \\
837 \\
740\end{array}$ & $\begin{array}{c}4990 \\
4141 \\
5148 \\
5248 \\
5113 \\
5141 \\
- \\
2985 \\
4770 \\
6723\end{array}$ & $\begin{array}{c}1473 \\
1053 \\
1047 \\
1436 \\
1326 \\
1552 \\
- \\
974 \\
1300 \\
1539\end{array}$ & $\begin{array}{r}191 \\
84 \\
313 \\
137 \\
412 \\
164 \\
- \\
0 \\
529 \\
181\end{array}$ & $\begin{array}{l}-47.8 \\
-14.4 \\
-12.2 \\
-14.1 \\
-13.7 \\
-16.4 \\
- \\
- \\
-10.7 \\
-16.7\end{array}$ & $\begin{array}{c}3740 \\
3740 \\
8180 \\
8180 \\
10770 \\
10770 \\
- \\
- \\
13810 \\
13810\end{array}$ & $\begin{array}{r}911 \\
935 \\
911 \\
935 \\
911 \\
935 \\
- \\
935 \\
911 \\
935\end{array}$ & $\begin{array}{c}(753) \\
773 \\
(753) \\
773 \\
(753) \\
773 \\
- \\
773 \\
(753) \\
773\end{array}$ \\
\hline
\end{tabular}

（注 1）主筋は全試聡体共通で $\phi 4\left(\sigma y=5990 \mathrm{~kg} / \mathrm{cm}^{2}\right)$ を4本使用。

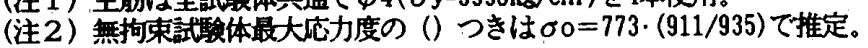


行った。シリーズ A は主に低強度材料を用いてその配筋 詳細の影響を評価したもので, シリーズ $\mathrm{B}$ は材料強度の 組み合わせを主なパラメータにしたものである。シリー ズ $\mathrm{A}$ は文献 6）に，・シリーズ $\mathrm{B}$ は文献 11）にその詳細を 報告してあるので，本論文ではその概要について示す。

表一1(a)（b）に各シリーズの試験体の諸元を示す。 試験体は $15 \mathrm{~cm} \times 15 \mathrm{~cm} \times 53 \mathrm{~cm}$ の直方体で，コアのみ で主筋のないものとして計画したが, 施工上最小限のか ぶりと主筋が必要であり，コアコンクリート幅 $D_{c}$ を 14 $\mathrm{cm}($ かぶり $0.5 \mathrm{~cm})$ とし，また無拘束コンクリート以 外には主筋 $(\phi 4)$ を配筋した。

シリーズ Aでは, コンクリート強度を $F_{c}=200 \mathrm{~kg} /$ $\mathrm{cm}^{2}$, 帯筋は 135 度標準フック付きのもので強度が $\sigma_{w y}$ $=3000 \sim 4500 \mathrm{~kg} / \mathrm{cm}^{2}$ のものを用い, 主なパラメータ を帯筋径 $(4 \sim 10 \mathrm{~mm})$, 帯筋間隔 $(S=23 \sim 140 \mathrm{~mm})$, および, 中間帯筋の有無とした 2 シリーズ（各シリーズ でコンクリート打設が同一バッチ) の計 15 体である。 試験体の名前は，例えば，2D10S140 が帯筋（中子な しの外周のみ) にD 10 を使い間隔 $S$ を $140 \mathrm{~mm}$ とした ものを, 3申 4S 70 が帯筋 (中子 1 本あり). に直径 4 $\mathrm{mm}$ の丸鋼を使い間隔 $S$ を $70 \mathrm{~mm}$ としたものを，それ ぞれ意味する。

シリーズ Bでは, コンクリート強度 $\left(F_{c}=400,600\right.$, $\left.800 \mathrm{~kg} / \mathrm{cm}^{2}\right)$, 帯筋強度 $\left(\sigma_{w y}=4000,8000,12000 \mathrm{~kg} /\right.$ $\mathrm{cm}^{2}$ ), 帯筋間隔 $(S=30,60 \mathrm{~mm})$, および, 帯筋種類 (溶 接閉鎖型筋, 角スパイラル)をパラメータとした 3 シリー ズ（各シリーズでコンクリート設計強度が同一）の計 26 体である。試験体の名前は, 例えば，F4Y4S30が コンクリート設計強度が $400 \mathrm{~kg} / \mathrm{cm}^{2}$ で, 帯筋に降伏強 度約 $4000 \mathrm{~kg} / \mathrm{cm}^{2}$ のものを 2 本 (外周のみ) 用い, 帯 筋間隔 $S$ を $30 \mathrm{~mm}$ としたものを意味する。帯筋種類は, 溶接閉鎖型帯筋を基本型とし，コンクリート設計強度が $800 \mathrm{~kg} / \mathrm{cm}^{2}$ のシリーズでスパイラルのものを製作した

(F 8 SP 30, F 8 SP 60)。

加力は一方向加力とし, 軸方向の変形は軸方向に測定 長約 $30 \mathrm{~cm}$ で, 4 䇢所で測定した。また, 帯筋の稆度は 部材長さ中央付近の $2 つ$ つ帯筋についてそれぞれ帯筋の 中央で外と内の 2 枚の歪ゲージで測定した。表一1(a) （b）には各試験体の使用した材料および対応する゙無拘 束試験体の最大忘力度も示してある。

\section{2 実験結果の概要}

本実験よりコアコンクリートの応力度－歪度関係をモ デル化するには, (i ) 軸方向歪度が, 特に最大耐力以 降測定区間によって大幅に変化すること, (ii) 同一断 面内のかぶりとコアのコンクリート，および主筋の軸方 向力負担分が分からないこと, 等の問題がある。本論文 では，以下のような仮定を設けて夷験結果を整理した。 まず，軸方向歪度の試験体軸に沿う分布は最大耐力ま
では均一とし, 最大耐力後は破壊領域を想定し破壊領域 外では除荷されるとして, 破壊領域の軸歪度を推定した。 なお，破壊領域の長さはシリーズ Bではコアコンクリー 卜剝落長さの測定値の全試験体の平均値の $16.6 \mathrm{~cm}$ 之 したが,シリーズAではコアコンクリートの軳落長さを 测定していなかったため断面せいと同一の $15 \mathrm{~cm}$ とし た。この破壊長さの設定は非常に重要であり，今後実験 で得られた破壊長さを用いるべきと考えているが，今回 のシリーズBでの破壊長さが断面せいと大きく変わらな かったことから，測定データが無い場合には断面せいを 用いることも容認されると考えられる。破壊領域外の除 荷剛性は弾性剛性と等しいと考え, コンクリートのテス トピースの弾性剛性の評価法に従い, 最大耐力点の $1 / 3$ の点の割線剛性とした。次に, 求められた破壊領域内の 断面の平均軸応力度一軸歪度関係からかぶりコンクリー 卜と主筋の応力度一歪度関係より求めた負担分を減じて コア内の平均軸応力度とした。ただし,かぶりコンクリー 卜は文献 12）に従い，また，主筋は歪硬化と座屈を無 視して完全弾塑性とした。

図-1にシリーズAのコア内の平均軸応力度一破壊領 域内の平均軸歪度の関係を使用帯筋別に示す。図一2に シリーズ Bのコア内の平均軸応力度一破壊領域内の平均 軸䄳度の関係をコンクリート強度と帯筋間隔別に示す。
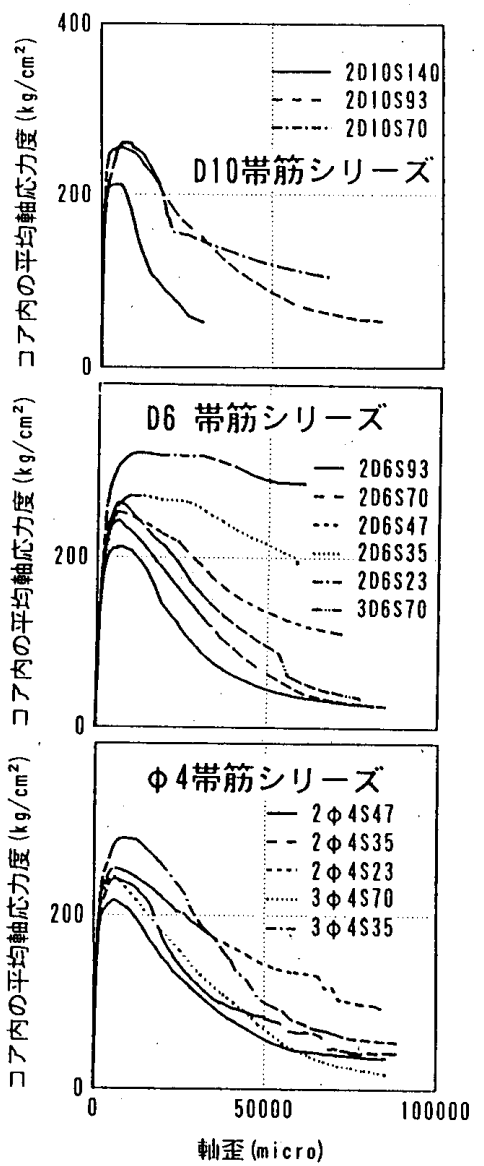

图一1 シリーズAのコア断面平均軸応力度一破壊領域平均軸丕 度関係 
コンクリート強度の低いシリーズ A では帯筋の径と間隔 と中子の有無により最大応力度とその時の軸歪度, およ び最大応力度以後の負勾配が大きく変化することが分か るが，コンクリート強度の高いシリーズ Bでは，带筋強 度の違いによる差は最大応力度点よりももむしろ最大応力 度点以後の負勾配およびその後の応力度が安定した領域 のみに表れることが分かる。また，シリーズAでは最大 応力度以後はコンクリートの圧壊とともにフックがはず れだすために，軸歪の増大とともに軸応力度は低下し， この安定した終局応力度の領域は明確ではない。した

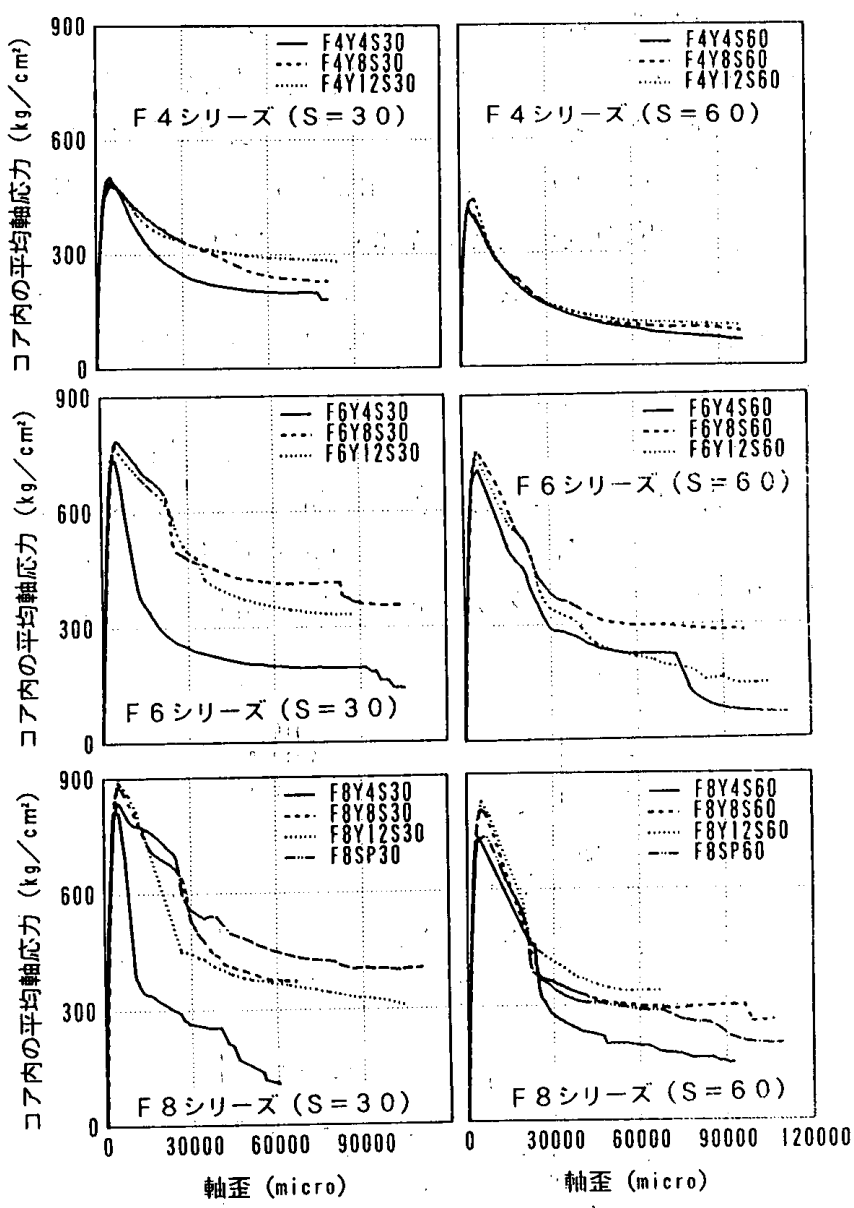

図一2 シリーズBのコア断面平均軸応力度一破壊領域平均軸稆 度関係

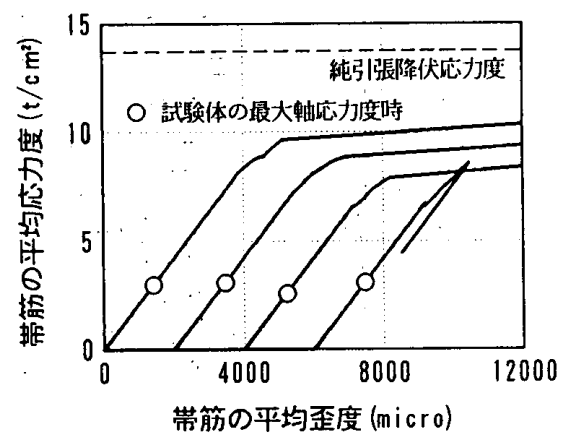

(a ) 帯筋の平均歪度一平均軸応力度関係 (F 8 SP 30)
がって, 帯筋がフックを有さない閉鎖型あるいはスパイ ラル筋の場合にこの安定した終局応力度の領域が存在す ると考えられる。

表一1(a)（b）の後半に各試験体のコア内の最大平均 軸応力度, 最大応力度時の破壊領域内の平均軸歪度と横 歪度, 安定終局応力度, さらに, 最大耐力後の負勾配を 示す。なお，横歪度は測定した帯筋の歪度の全平均とし た。また, 最大耐力後の剛性と安定した終局応力度の評 価法は各シリーズで異なり，それぞれ文献 6)，11）に示 した方法による。

\section{3 軸歪度一軸応力度一横歪度一帯筋応力度関係}

図一-3(a) はシリーズBの試験体 F 8 SP 30 に添付し た歪ゲージより推定した帯筋の平均軸歪度一平均軸応力 度関係である。なお, 図は 4 箇所の測定点について示し ているが，見やすいように各測定点の横軸を 2000 micro づつずらして示してある。ここで, 平均軸歪度は, 帯筋の各測定点で引張側と圧縮側の両端に添付された 2 枚の歪ゲージの値の平均, すなわち，重心位置の歪度と した。また，その時の帯筋の平均軸応力度は帯筋断面の 平面保持を仮定し前述の: 2 枚の歪ゲージより断面の各部 の歪分布を求め, 断面各部において帯筋の応力度一歪度 の履歴を与え, さらに, 全断面で積分して求めた。図を みると，帯筋には軸方向力の他に 3.3 節で示すような中 間荷重が生じるため, 曲げモーメントと軸力の相互作用 により帯筋の軸力は純引張を受けた場合の降伏引張力ま で達しないことが分かる。すなわち，引張端のゲージが 降伏するまでは弾性であるが, このゲージが降伏すると 同時に応力度一歪度関係の勾配が軟化し始め, 純引張を 受ける場合の応力度－歪度関係から外れてくることが分 かる。

図一3(b) はシリーズ B の試験体 F 8.Y12S30 の軸歪 度一軸応力度一横歪度 (帯筋の平均歪度) 一帯筋の平均 応力度関係である。図中の○は最大応力度点であるが, このときの帯筋の平均応力度は純引張を受ける場合の降 伏応力度にはまだかなりの余裕がある。これは，試験体 の軸方向最大応力度が帯筋強度にはあまり影響されない

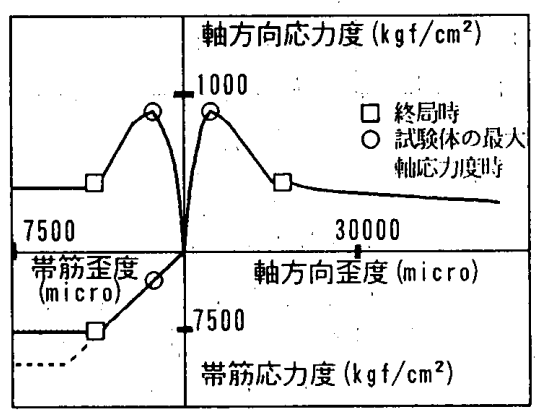

(b) 軸方向歪度一軸方向応力度一帯筋平均昰度 一帯筋平均応力度関係 (F8Y12S30) 
ことと一致する。この後, 帯筋の平均応力度は増加し の点で歪度が増加し, 前述した理由よりあたかも降伏し たような挙動となる。すなわち，拘束コンクリートの軸 方向応力度一軸歪度関係の最大応力度点およびその後の 負勾配を評価するためには帯筋の○の点との関係を, 安 定した終局状態の応力度を評価するためには口の点との 関係を明らかにする必要があることが分かる。本論文で は, 材軸方向亡断面内で拘束が不均一である正方形帯筋 により拘束された鉄筋コンクリート柱のコア内の軸方向 応力度一軸歪度関係をこの 2 つの帯筋の応力度による拘 束応力度に着目してモデル化した。なお，図一3の○の 点の拘束応力度を $\sigma_{t p}, \square$ 点の拘束応力度を $\sigma_{t u p}$ 之す る。なお， 口の点は，図一 $3(\mathrm{a})$ で示したように帯筋昰 度一帯筋応力度関係においてその勾配が急変する点之定 義した。ただし，加力途中で減力する場合は過去の最大 応力度点とした。なお， $\sigma_{\text {tup }}$ の実験値は口の点の帯筋の 応力度の全測定点の平均より算出した。

\section{3. 拘束されたコンクリートの軸応力度一軸歪度関係の} モデル化

モデル化に際し，単位は $\mathrm{kg}$ と $\mathrm{cm}$ を用いた場合につ いて示す。また, 符号は軸歪度と軸応力度が縮みと圧縮 を正, 帯筋歪度と帯筋応力度が伸びと引張を正とした。 さらに, 式の適用範囲は断わらない限り実験でのパラ メータの範囲である。すなわち、コンクリート強度は $200 \mathrm{~kg} / \mathrm{cm}^{2} \leqq \sigma_{c} \leqq 900 \mathrm{~kg} / \mathrm{cm}^{2}$, 帯筋強度は $3000 \mathrm{~kg} / \mathrm{cm}^{2}$ $\leqq \sigma_{w y} \leqq 12000 \mathrm{~kg} / \mathrm{cm}^{2}, \quad S / D_{\mathrm{c}}$ は $0.15 \leqq S / D_{c} \leqq 1$ 程度を 適用範囲と考える。

\section{1 最大応力度点 $\left(\sigma_{c p}, \varepsilon_{c p}\right)$ の評価}

図-4(a) (b) に帯筋歪度の測定值より得られた拘束 応力度とコアコンクリートの無拘束試験体からの最大応 力度増分 $\Delta \sigma_{c p}$ との関係を示す。図 (a) は最大応力度 時の帯筋歪度の測定值より得られた拘束応力度 $\sigma_{t p}$ を, 図 (b) が終局時の帯筋歪度の測定値より得られた拘束 応力度 $\sigma_{t u p}$ を横軸にとったものである。また，同様に 図一5(a) (b) に帯筋歪度の測定値より得られた拘束応 力度 $\sigma_{t p}$ および $\sigma_{t u p}$ とコアコンクリートの無拘束試験体 からの最大応力度時の軸歪度増分 $\Delta \varepsilon_{c \rho}$ との関係を示す。 図中の実線は文献 10）による評価式であり, 最大応力 度時の帯筋歪度の測定値より得られた拘束応力度 $\sigma_{t p}$ を 用いた場合には, 式（1）（2）で表され, ほぼ実験値 を推定していることが分かる。

$$
\begin{aligned}
& \Delta \sigma_{c p}=\sigma_{c p}-\sigma_{c}=4.1 \cdot \sigma_{t p} \cdots \cdots . . . \\
& \Delta \varepsilon_{c p}=\varepsilon_{c p}-\varepsilon_{c}=0.00015 \cdot \sigma_{t p}
\end{aligned}
$$

これは, 序で述べたように, 角型補強筋より生じるコ アコンクリート内の平均拘束応力度の軸方向応力度－歪 度関係に及ぼす効果は均等圧のものとほぼ等しいことを 意味する。したがって, 最大応力度時の拘束応力度 $\sigma_{t \rho}$ が評価できれば,最大応力度点が評価できることになる。 そこで, 実験值よりこの拘束応力度 $\sigma_{t \rho}$ を評価すること を試みる。まず，拘束応力度は带筋の歪度より式（3） で表される。

$$
\begin{aligned}
& \sigma_{t p}=K_{c f \cdot \varepsilon_{t p}} \quad\left(\leqq \sigma_{t u p}\right) \\
& K_{c f}=\frac{a_{w} \cdot E_{s}}{D_{c} \cdot S} \ldots \ldots \ldots \ldots \ldots \ldots
\end{aligned}
$$

ここで， $K_{c s}$ は拘束剛性で， $a_{w}$ は帯筋の有効な断面積, $E_{s}$ は帯筋のヤング係数， $\varepsilon_{t p}$ は最大応力度時の帯筋の断 面図心位置での歪度， $D_{c}$ はコア長さ， $S$ は帯筋間隔で ある。また， $\sigma_{\text {tup }}$ の評価法は後述する。

式 (1) （3）の 3 式の独立した未知数は $\sigma_{c p}, \varepsilon_{c p}$, $\sigma_{t p}, \varepsilon_{t p}$ の 4 つであり, 例えば， $\varepsilon_{c p}$ と $\varepsilon_{t p}$ の関係が特定 できれば，最大応力度点が評価できることになる。図一 6(a) は実験で得られた $\sigma_{c p}$ より式（1）により逆算さ れた $\sigma_{t p}$ を用いて, 式 (2)（3）で求めた $\varepsilon_{c p}$ と $\varepsilon_{t p}$ の 比を縦軸に横軸に式（4）で示す拘束剛性をとって示し たものである。ただし，逆算された $\sigma_{t p}$ が負になるもの 亡中子筋のあるものは除いた。本論文では以降,この $\varepsilon_{c \rho} / \varepsilon_{t p}$ を最大応力度時のポアソン数と呼ぶ。このポア ソン数は図から明らかなように右上がりの傾向を示して いる。さらに，帯筋による拘束応力が一部に集中して加

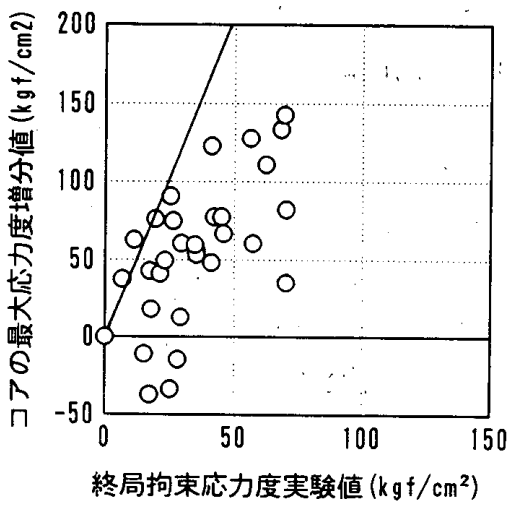

(b) $\sigma_{t u p}$ の最大応力度に対する影響

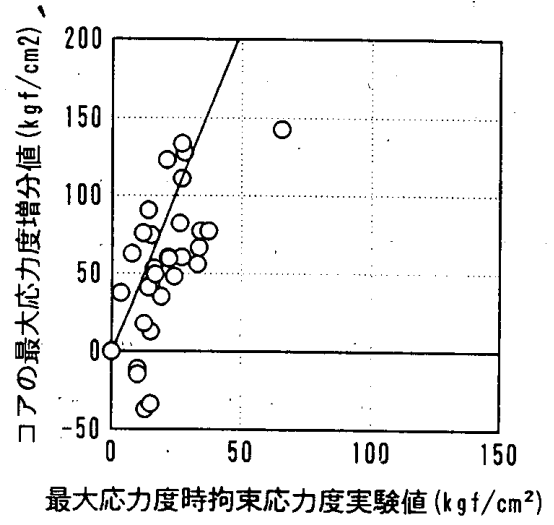

（a） $\sigma_{t p}$ の最大応力度に対する影響

图一4 拘束応力度実験傎の最大応力度増分に対する影響 


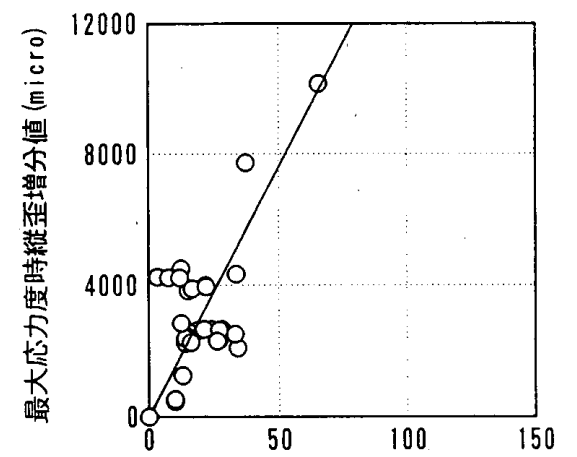

最大応力度時拘束応力度実験值 $\left(\mathrm{kgf} / \mathrm{cm}^{2}\right)$

（a ） $\sigma_{t \rho}$ の最大応力度時軸歪度に対する影響

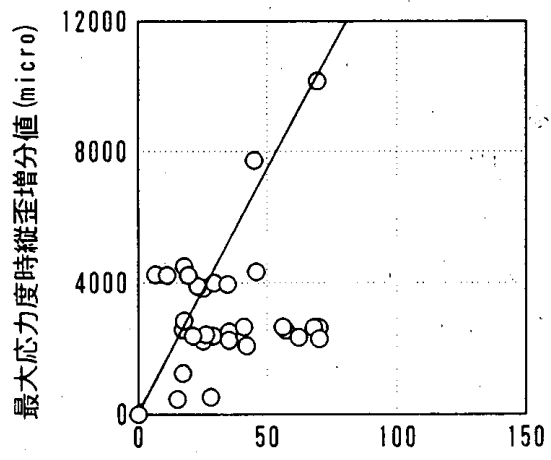

䊏局拘束応力度実験值 $\left(\mathrm{kgf} / \mathrm{cm}^{2}\right)$

(b) $\sigma_{t u p}$ の最大応力度時軸昰度に対する影響

図一5 拘束応力度実験值の最大応力度時軸歪度増分に対する影響

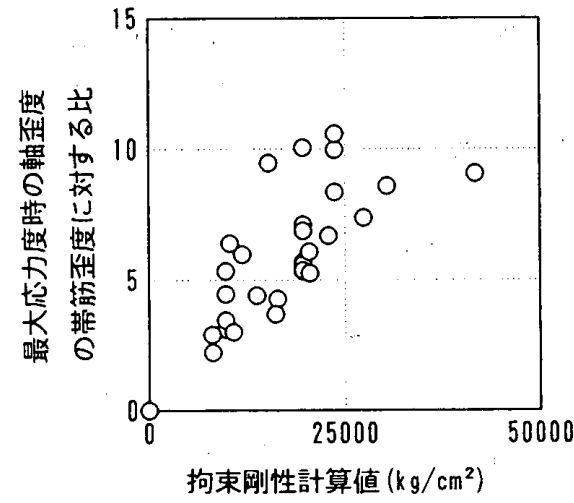

(a) 拘束剛性 $\left(K_{c s}\right)$

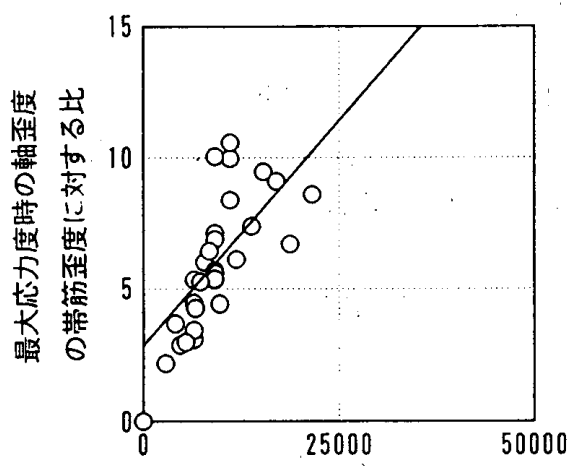

有効拘束䣓性計算値 $\left(\mathrm{kg} / \mathrm{cm}^{2}\right)$

(b) 有効拘束剛性 $\left({ }_{e} K_{c f}\right)$

図一拘束剛性と最大応力度時の $\varepsilon_{c p} / \varepsilon_{t p}$ の関係

わるため，その点での横歪度すなわち帯筋の歪度が拘束 されているコンクリート全体の横歪度を代表しておら ず，したがって，最大応力度時のポアンン数は同一の拘 束剛性でも $S / D_{c}$ が大きければ大きくなる傾向があるこ とも推定しうる。そこで，集中拘束係数 $f(\alpha) ， g\left(N_{B U N}\right)$ を用いて, 式 ( 5 ) の形で有効拘束剛性 ${ }_{e} K_{c r}$ を定義する。

$$
\begin{aligned}
& { }_{e} K_{C f}=K_{C f} \cdot f(\alpha) \cdot g\left(N_{B U N}\right) \\
& f(\alpha)=\sqrt{\alpha} \ldots \ldots \ldots \ldots \ldots \ldots . \\
& g\left(N_{B U N}\right)=1 / N_{B U N}^{2} \cdots \ldots \ldots \ldots . \\
& \alpha=S / D_{c} .
\end{aligned}
$$

$N_{B U N}$ : 断面内の帯筋による分割数で中子筋のないとき は 1 （適用範囲 : $\left.N_{B U N}=1,2\right)$;

集中拘束係数 $f(\alpha)$ :は帯筋間隔が 0 （すなわち $\alpha=0 ）$ で $K_{c f}$ に無関係に ${ }_{e} K_{c f}=0$ となり， $\alpha$ の増大により集中 拘束係数が大きくなるように決めた。図一6(b) は横軸 に有効拘束係数をとり図（a）を修正したものである。 これを最小自乗法により推定したのが式（8）である。

$$
\varepsilon_{c p} / \varepsilon_{t p}=2.8+0.00035 \cdot{ }_{e} K_{c s}
$$

以上より, 最大応力度時の拘束応力度 $\sigma_{t p}$ は式 $(2)(8)$ を用いて，

$$
\sigma_{t p}=\frac{2.8+0.00035 \cdot{ }_{e} K_{c f}}{0.00015} \cdot \varepsilon_{t p}-\frac{\varepsilon_{c}}{0.00015}
$$

となり，これと式 (3) との交点の式 (10) が拘束応力

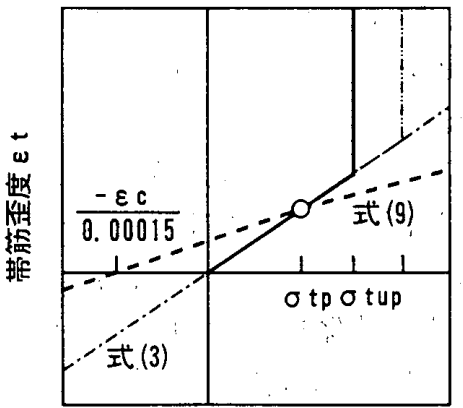

拘束応力度 $\sigma \mathrm{t}$

最大応力度時の拘束応力度 $\sigma$ tpの算定

図一7 最大応力度時の拘束応力度, 評価の概念図

度 $\sigma_{t p}$ の解となる。図一7は, 横軸に拘束応力度を, 縦 軸に帯筋の昰度をとって, 式（3）と（9）の関係を模 式的に表したものであるが，図より明らかなように， $\sigma_{t p}>\sigma_{t u p}$, あるいは, $\sigma_{t \rho}<0$ の時は, $\sigma_{t p}=\sigma_{t u p}$ となる。

$$
\sigma_{t p}=\frac{\varepsilon_{c}}{\left(2.8+0.00035 \cdot{ }_{e} K_{c s}\right) / K_{c f}-0.00015}
$$

(ただし， $\sigma_{t p}>\sigma_{t u p}$, あるいは, $\sigma_{t p}<0$ の時は, $\left.\sigma_{t p}=\sigma_{t u p}\right)$ 次に集中拘束係数 $g\left(N_{B U N}\right)$ であるが; $g\left(N_{B U N}\right)$ は中子筋 のある場合に拘束集中度が緩和されることを表す関数で ある。図一8はシリーズAの中子筋のある試験体につい て最大応力度の実験値に適合する $g\left(N_{B U N}\right)$ を 0 を下限に 


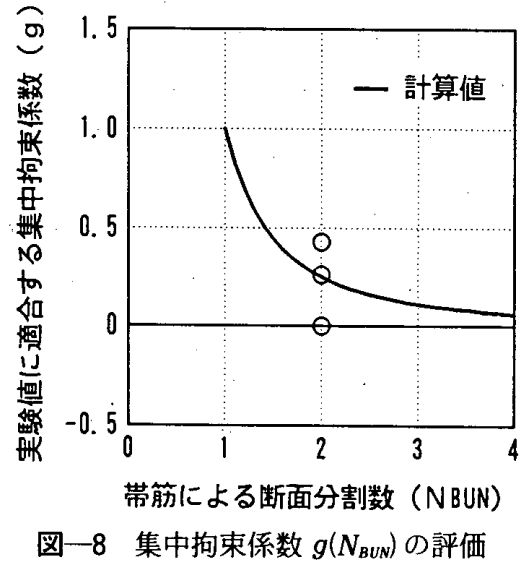

して縦軸にとり， $N_{B U N}$ を横軸にとって示したものであ り,これが $N_{B U N}$ が 1 のとき $g\left(N_{B U N}\right)$ が 1 に, $N_{B U N}$ が無 限大で $g\left(N_{\text {BUN }}\right)$ が 0 に漸近する式として仮定したのが式 （7）である。ただし，中子筋が複数ある試験体につい ては未検討であるので, 現在のところその適用範囲を $N_{B U N}=1,2$ とし, 3 以上については今後の検討課題とす る。

結局，(10）式より求められた $\sigma_{t p}$ を式（1）（2）に 代入することにより， $\sigma_{c p}$ と $\varepsilon_{c p}$ が求まる。図一 9 に $\sigma_{c \rho}$ と $\varepsilon_{c \rho}$ の実験值と計算値の比較を示す。 $\sigma_{c p}$ の計算値は 実験值をおおむ推定し，また， $\varepsilon_{c p}$ は軸歪度が小さい 範囲では精度がよかったが， $\varepsilon_{c p}$ の軸歪度が大きい領域 での精度が悪く今後の検討課題である。

\section{2 負勾配 $\left(E_{u p}\right)$ の評価}

$E_{u p}$ は最大応力度時の拘束応力度 $\sigma_{t \rho}$ との相関を検討 した。図一10 は横軸に $\sigma_{t p}$ を縦軸に実験より得られた $E_{u p}$ を取ったものであるが，これを横軸が 0 で無拘束コ ンクリートと一致し無限大で 0 に漸近する式として最小 自乗法で求めたものが式 (11) であり, 図中にコンクリー 卜強度別に示してある。

$$
\begin{aligned}
& E_{u p}=\frac{E_{u}}{1+1.26 \cdot \sigma_{t p}} \cdots \cdots \ldots . . . . . \\
& E_{u}=\left(\sigma_{c}-100\right) /\left(\varepsilon_{c}-0.005\right)
\end{aligned}
$$

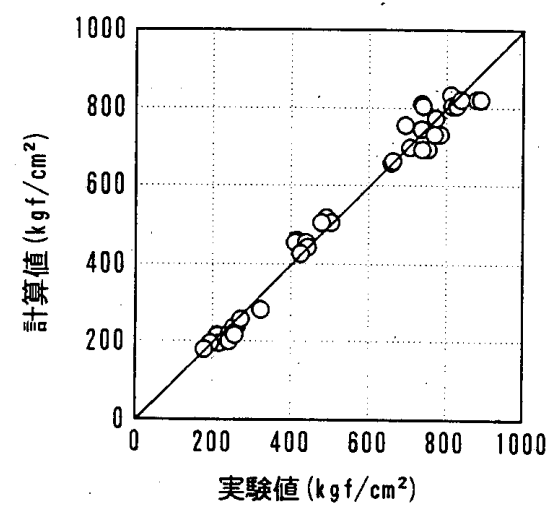

(a ) 最大応力度

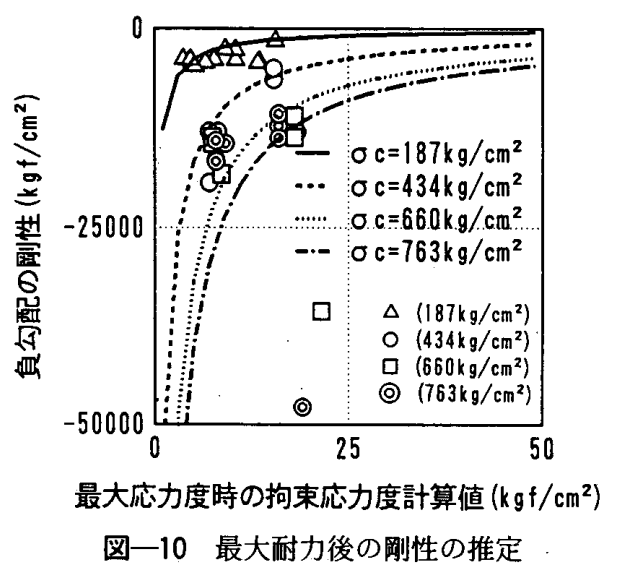

$\varepsilon_{c}=1.37 \cdot 10^{-6} \cdot \sigma_{c}+0.00169$

ここで, $E_{u}, \varepsilon_{c}$ は無拘束試験体の負勾配の剛性と最大 応力度時の軸歪度であり, 野口の提案.12)に従った。

\section{3 終局応力度 $\left(\sigma_{u p}\right)$ の評価}

ここでは, 文献 13）を参考に軸方向加力柱の終局状 態として角度 $\theta$ の平面内で滑りを生じ帯筋の反力によ る摩擦のみで軸方向力に抵抗している状態を想定し，そ のときの軸方向応力度 $\sigma_{u \rho}$ を式 (12) で求めた。ただし, 式（12）は带筋として閉鎖型筋を用いた場合の式で, 通 常のフック付きの帯筋の場合には $\sigma_{u p}=0$ とする。

$$
\begin{aligned}
& \sigma_{u p}=\sigma_{t u p} \cdot \frac{c \cdot s+\mu\left(\sigma_{c}\right) \cdot s \cdot s}{c \cdot s-\mu\left(\sigma_{c}\right) \cdot c \cdot c} \ldots \ldots \ldots . \\
& \mu\left(\sigma_{c}\right)=0.32+0.00064 \cdot \sigma_{c} \quad(\leqq 1)
\end{aligned}
$$

(適用範囲 : $400 \mathrm{~kg} / \mathrm{cm}^{2}<\sigma_{c}<900 \mathrm{~kg} / \mathrm{cm}^{2}$ )

$$
\begin{aligned}
& \sigma_{t u p}=\frac{a_{w} \cdot \sigma_{w y}}{D_{c} \cdot S} \cdot \frac{2 /\left(1+C_{0}\right)+N_{B U N}-1}{N_{B U N}+1} \\
& C_{0}=(1 / 2) \cdot\left(D_{c} / \phi_{w}\right) \cdot \gamma \\
& \gamma=0.00005 \cdot \sigma_{w y} \quad(\gamma \leqq 2)
\end{aligned}
$$

ここで, $c=\cos \varepsilon, s=\sin \theta$, である。なお, $\theta$ は文献 13) に従い 45 度とした。 $a_{w}$ は帯筋の有効な断面積， $\phi_{w}$, $\sigma_{w y}$ は帯筋の直径と降伏応力度である。また， $D_{c}$ はコ ア長さ， $S$ は帯筋間隔である。さらに， $N_{B U N}$ は前述し たように，断面内の帯筋による分割数である。

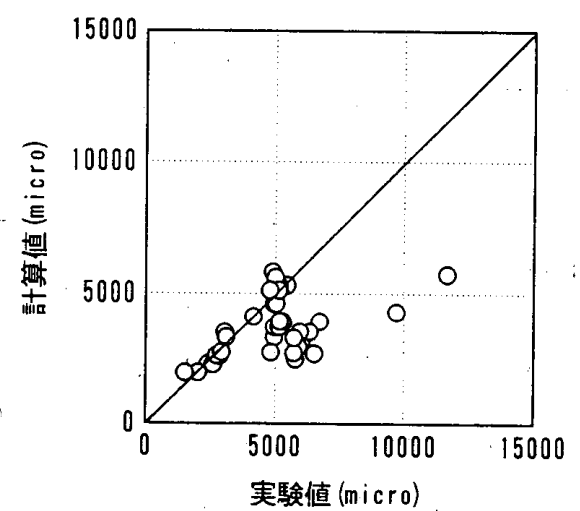

(b) 最大応力度時軸歪度

图一9 最大応力度点の実験値之計算値の比較 

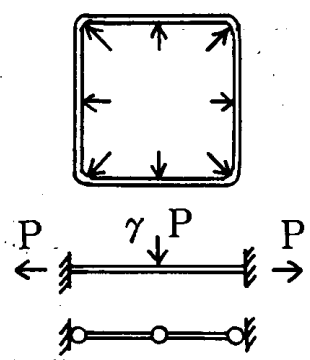

図一11 带筋による拘束概念

$\sigma_{\text {tup }}$ は終局時の拘束応力度であるが, 帯筋の降伏応力 度 $\sigma_{w y}$ を用いた拘束応力度を式 (14) の右辺の式で低減 したものとなっている。図一11 は帯筋にコンクリート より加わる力を模擬したものであるが，鈴木らの指摘7 のように, この中間荷重のために中子筋以外の外側の帯 筋は純引張を受ける場合の降伏応力度まで達しない。そ

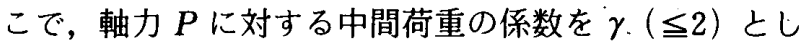
て，帯筋の降伏メカニズムを図一11のように仮定する。 さらに，帯筋の断面の降伏時モーメントー軸力相互関係 を,

$$
\begin{aligned}
& \left(P / P_{y}\right)+\left(M / M_{y}\right)=1 \cdots \\
& P_{y}=\pi \cdot\left(\phi_{w} / 2\right)^{2} \cdot \sigma_{w y} \\
& M_{y}=(\pi / 4) \cdot\left(\phi_{w} / 2\right)^{3} \cdot \sigma_{w y}
\end{aligned}
$$

とモデル化すると, 中子筋の無い場合の $\sigma_{t u p}$ が式 (18) のように求まる。

$$
\sigma_{t u p}=\frac{a_{w} \cdot \sigma_{w y}}{D_{c} \cdot S} \cdot \frac{1}{\left(1+C_{0}\right)}
$$

式（18）における $1 /\left(1+C_{0}\right)$ が帯筋に生じる中間荷重に よる終局拘束応力度の低減係数である。式 (18) に低減 係数を 1 とした中子筋による拘束応力度の寄与分を加え ることにより，式·(14) が得られる。ここで，図一3の $\square$ 口点の実験値に適合する $\gamma$ を式 (14) より逆算した ものを図-12 に示す。横軸は帯筋の降伏応力度である。 なお，通常フック付きの帯筋の場合には $\sigma_{\text {tup }} に$ 達した のちに応力度が低下していくことを考虑し， $\sigma_{u p}=0$ と したが， $\gamma$ 算定には意味があるので図一12のデータ には含めた。算定された $\gamma$ には図-11 と式（17）の仮

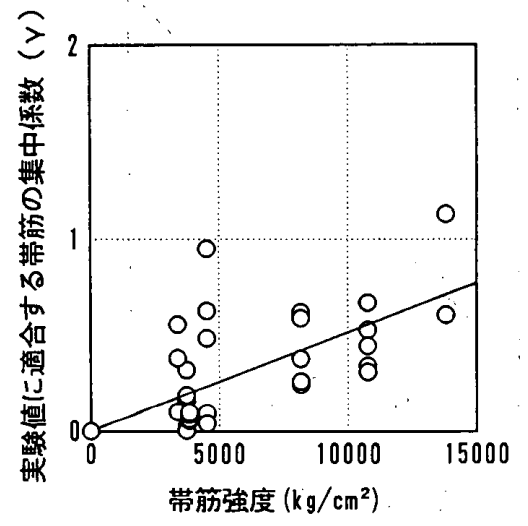

図一12 実験值に適合する帯筋の集中係数 $\gamma$
定により，-帯筋の径，長さの影響が考慮されているが， 図一12を見ると $\gamma$ は $\sigma_{w y}$ と相関があり，これを最小自 乗法で求めたのが，式（16）の $\gamma$ の式である。

次に，終局時のコンクリートの摩擦係数 $\mu\left(\sigma_{c}\right)$ である が，実験より得られた終局時の軸応力度と終局時の拘束 応力度を用いて式（12）より逆算された $\mu$ 安縦軸に, 横軸にコンクート強度をとって図一13 に示す。コンク リート摩擦係数はコンクリート強度に相関がありこれを 最小自乗法で評価したものが式（13）である。以上より 求められた終局軸応力度の実験值と計算值の比較を図一 14 に示す。

なお，横補強筋に閉鎖型帯筋を用いた場合でも帯筋の 降伏強度が低い場合には破断により耐力が段階的に減少 する。これは終局時の帯筋の応力度と降伏応力度との差 (すなわち，終局時の帯筋の余裕度）などによる制限が 必要であろう。

3.4 軸応力度一軸歪度曲線のモデル化

図一15(a)（b）は無拘束およびコア内のコンクリー トの平均化された応力度－歪度関係である。無拘束のコ ンクリートのモデルは文献 12) による。3 節で示した各 量を用いで，コアのコンクリートの各区間は以下の式で 表す ( $p_{w}=0$ で無拘束と一致)。

$$
\begin{gathered}
\text { 区間 OA }: \frac{\sigma}{\sigma_{c p}}=1-\left\{1-\left(\frac{\varepsilon}{\varepsilon_{c p}}\right)\right\}^{n} \\
\left(n=E_{c p} \cdot \varepsilon_{c p} / \sigma_{c p}\right)
\end{gathered}
$$

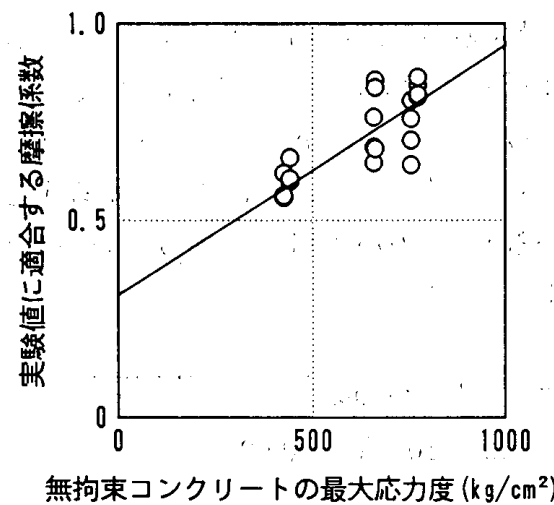

図一13 実験に適合するコンクリートの摩擦係数 $\mu$

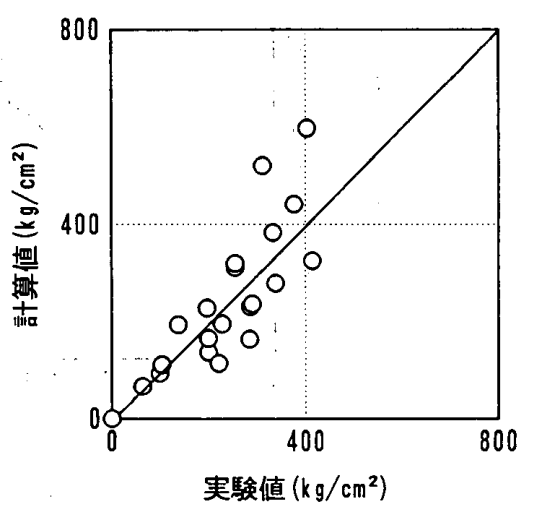

図一14 終局軸応力度の実験値と計算值の比較 

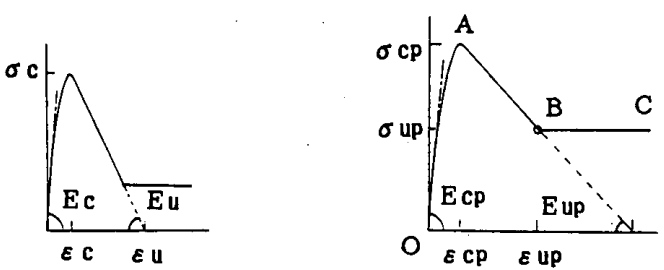

(a) 無拘束コンクリート

(b ） コア内のコンクリート 図一15 コンクリートの平均化された応力度一歪度関係

区間 $\mathrm{AB}: \sigma=E_{u p} \cdot\left(\varepsilon-\varepsilon_{c \rho}\right)+\sigma_{c \rho}$

区間 $\mathrm{BC}: \sigma=\sigma_{u \rho}$

ここで,

$$
E_{c \rho}=210000 \cdot \sqrt{\sigma_{c \rho} / 200}
$$

とする。また，無拘束の試験体の最大応力度 $\sigma_{c}$ とヤン グ係数 $E_{c}$ は,

$\sigma_{c}:$ 無拘束柱の実験值あるいは $0.85 \cdot \sigma_{B}$

$\left(\sigma_{B}: \phi 10 \mathrm{~cm}\right.$ のシリンダー強度 $)$

$E_{c}=210000 \cdot \sqrt{\sigma_{c} / 200}$

とする。無拘束角柱コンクリートの最大応力度は既往の 実験では $\phi 10 \mathrm{~cm}$ のシリンダー強度の $0.7 \sim 1.0$ 程度に ばらつくことを考慮している。

\section{4. モデルと実験との比較}

図一16 はシリーズ B の試験体を対象にコンクリート 強度別に最大応力度の無拘束試験体からの増分值の実験 値を帯筋間隔を横軸にとって示したものである。同図に はモデルによる計算値も示してあるが, 本試験体の場合 帯筋間隔とコンクリ゙ート強度が同一ならば最大応力度の 増分に対する帯筋強度の影響はないため, モデルはすべ ての帯筋強度の試験体と対応する。図を見ると，実験值 が帯筋強度により影響されていないことが分かり,また， モデルは実験值とおおむね対応していることが分かる。

シリーズAの試験体の内，ほぼ同程度の補強筋量で太 い補強筋が広い間隔で配筋されているもの(2D10S140) と, 細い補強筋が密な間隔で配筋されているもの(2 4S 23）のコアの平均応力度一破壊領域の歪度関係を実 験值と計算值で比較して図-17(a)（b) に示す。補強 筋量が同程度でも，その配筋法によりその挙動が変わっ

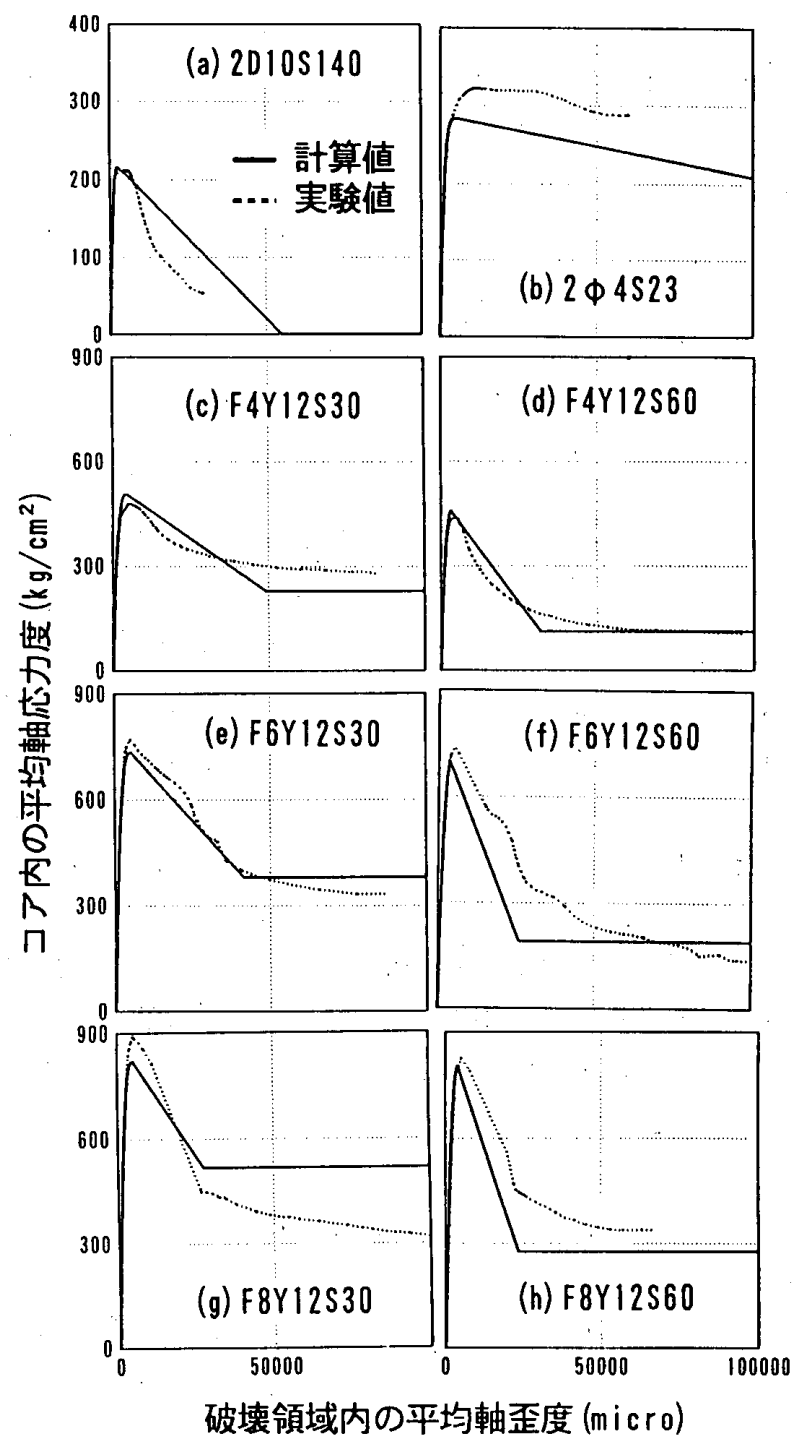

図-17 コアアの平均応力度－破壊領域の歪度関係の実験値と計 算值の比較

てくること, および，本モデルがその傾向を評価し得る ことが分かる。また，シリーズ Bの試験体の内，帯笳強 度に最も高い $12000 \mathrm{~kg} / \mathrm{cm}^{2}$ を用いたシリーズのコアの 平均応力度一破壊領域の昰度関係を実験值と計算値で比 較して図一17(c)～(h) に示す。コンクリート強度およ び帯筋間隔による挙動の変化をよく評価し得ることが分 かる。

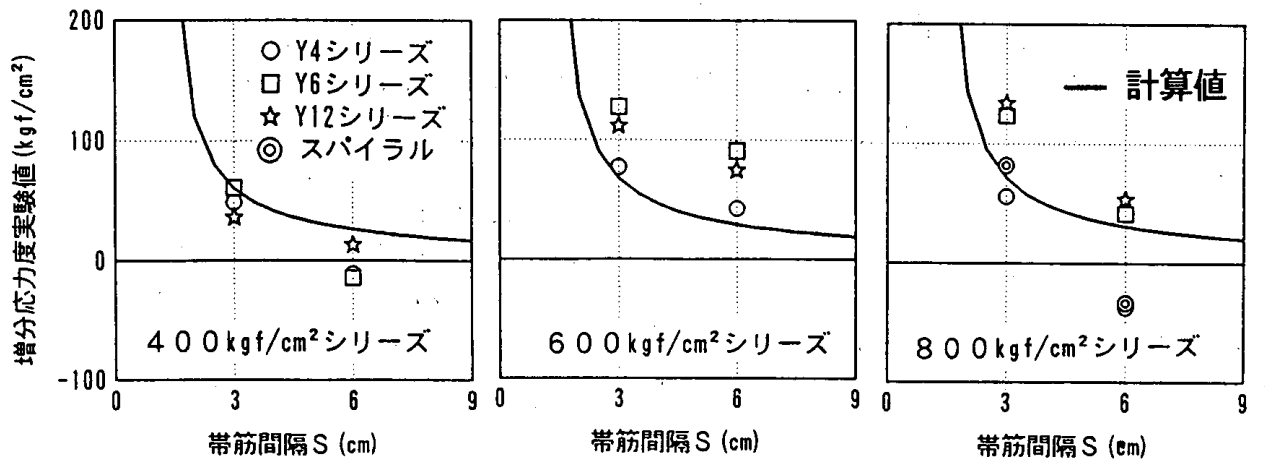

图一16 帯筋間隔とコンクリート強度の最大応力度増分に対する影響 


\section{5. まとめ}

正方形帯筋により拘束される軸方向加力実験を，配筋 詳細の異なる試験体シリーズ，および，コンクリートお よび帯筋の材料強度の組み合わせを主なパラメータにし たシリーズの 2 シリーズを行い, 以下のことが得られた。 （1）試験体の最大応力度時の軸方向応力度と昰度はそ のときの帯筋の測定された歪度から求めた拘束応力度に より，均等王を受ける既往の実験式で評価できる。

（2）最大応力度以後の負勾配の傾きは（1）で示した 最大応力度時の拘束応力度に影響される。

（3）横補強筋に閉鎖型帯筋を用いた場合には終局時に 安定した軸方向応力度を示す傾向がある。また，この応 力度は終局時の拘束応力度に影響を受ける。終局時拘束 応力度とは, 帯筋が曲げを受けるために軸方向の降伏応 力度に達せずに軸歪度が伸びる点の拘束応力度である。

以上の実験結果を基に，2つの拘束応力度を推定する ことにより正方形帯筋により拘束される軸方向忍力度一 歪度関係を以下のようにモデル化した。

（4）最大応力度時の拘束応力度 $\sigma_{t p}$ は最大応力度時の ポアソン数を拘束が不均一であることを考慮した有効拘 束剛性を用いて推定することにより，式 (10) で評価す る。なお，単位は $\mathrm{kg} と \mathrm{~cm}$ とする。

（5）破壊領域内のコアコンクリートの最大軸応力度, 軸歪度および負勾配の剛性は $\sigma_{t p}$ を用いそれぞれ式 $(1)$

(2) (11) で求められる。

（6）終局時の拘束応力度 $\sigma_{t u p}$ は外周の帯筋にコンク リートより曲げが加わることをモデル化し，式 (14) で 評価する。

（7）破壊領域内のコアコンクリートの終局応为度 $\sigma_{u \rho}$ は $\sigma_{t u p}$ を用い式 (12) で求められる。ただし，带筋が 通常のフック付きの場合には $\sigma_{u p}=0$ とする。

モデルと実験結果を比較した結果，以下のことが分 かった。

(8) $\cdots \sigma_{c p}, E_{u \rho}, \sigma_{u \rho}$ の計算値は実験值をおおむね推定 し，また， $\varepsilon_{c \rho}$ は軸歪度が小さい範囲では精度がよかっ たが， $\varepsilon_{c p}$ の軸歪度が大きい領域での精度が悪く今後の 検討課題となった。

(9）これらの点を用いてコアコンクリートの軸応力度 一妻度関係をモデル化し，実験と比較した結果，モデル はほほ配筋量の同じ武験体の配筋法の違いによる挙動の 差や，コンクリート強度および帯笳間隔による挙動の変 化をよく評価し得ることが分かった。

\section{謝 辞}

本研究の一部は, 文部省科学研究費補助金・一般研究 (c)（課題番号：62550415, 研究代表者 : 新潟大学加藤 大介)，および文部省科学研究費補助金・総合研究 $(A)$ （課題番号：01302048，研究代表者：東京大学青山博之 教授）により行った。閉鎖型帯筋は住友電工工業(株)
より，また，スパイラル筋は高周波熱錬（株）よりいた だいた。また，実験およびデー夕解析を行うに当たり， 羽廣重夫氏 (大成建設, 当時新潟大学大学院生), 福井 浩二氏 (大林組, 当時新潟大学卒研生), 渡辺房夫氏 (長 建設計事務所, 同), 安藤正貴氏（福田組, 同) および 高田義久氏（同）に御協力いただいた。ここに関係各位 に謝意を表します。

\section{参考文献}

1) Kent, D.C. and Park, R. : Flexural Member with Confined Concrete, Proceedings, ASCE, Vol. 9, ST7, pp. 1969 1990, July 1971

2) Bertero, V.V., Popov, E. P., et. : MECHANICAL BEHAVIOR OF LIGHTWEIGHT CONCRETE CON. FINED BY DIFFERENT TYP ES OF LATERAL REINFORCEMENT, Report of College of Engineering, University of California, Berkeley, Cali fornia, May. 1979

3）六車ほか：横補強による高強度コンクリートの勒性改善 に関する研究 (その 2 応力゙ー昰曲線のモデル化), 日本 建築学会大会学術講演梗概集, pp. 1915 1916, 昭和 58 年

4）山田稔, 河村 広ほか：コンクリートの弾塑性変形並 びに崩壊性状に関する研究（I）（II），日本建築学会大 会学術講演梗概集, pp. 1325 - 1328, 昭和 54 年

5) Shamim A. Sheikh and S.M. Uzumeri, “Analytical Model for Concrete Confinement in Tied Columns, ST12 ASCE, December, pp. 2703 2722, 1982

6）加藤大介, 羽廣重夫：鉄筋コンクリート造角柱試験体の 軸方向圧縮実験の評価に関する研究, 第 11 回コンクリー 卜工学年次論文報告集，pp. 287～292，1989

7）鈴木計夫, 中塚 佶ほか：角形横補強筋によるコンファ イン゙ドコンクリートの拘束機構と強度・変形特性, 第 11 回コンクリート工学年次論文報告集, pp. $449 \sim 454$, 1989

8）清水弘道：鉄筋コンクリート柱における横方向補強筋の 拘束効果の解析研究; 日本建築学会大会学術講演梗概集, pp. 00 00, 昭和 57 年

9) Shualb H. Ahmad and Surendra P. Shah, : Complete Triaxial Stress-Strain Curves for Concrete, ASCE, Vol. 108, No. ST4, April, pp. 728 742, 1982

10) Richart, F.E., et., : A Study of the Failure of Concrete Under Combined Compressive Stress, Bulletin No. 185, University of Illinois Eng. Experiment Station, Urbana, Nov. 1928

11）加藤大介 -: 高強度材料を用いた RC 造角柱の軸方向圧縮 実験の評価に関する研究，第 12 回コンクリート工学年次 論文報告集，pp. 439～444，1990

12）野口 博：文部省科学研究費研究資料報告, 平成元年

13）谷：資信ほか：鉄筋コンクリート構造物の復元力特性(ス パイラルフープによって補強されたシリンダー試験体の 最大耐力以後の特性について), 日本建築学会大会, pp. 1389 1390, 昭和 51 年

(1990 年 3 月 13 日原稿受理, 1991 年 1 月 28 日採用決定) 